\title{
New human case reports of cutaneous leishmaniasis by Leishmania (Viannia) naiffi in the Amazon region, Brazil
}

\author{
Luanda de Paula FIGUEIRA ${ }^{1,2}$, Fabiane Veloso SOARES ${ }^{1,2}$, Roberto Daibes NAIFF JÚNIOR ${ }^{1}$, Alana Cristina \\ VINHOTE-SILVA $^{1}$, Susi Simas da SILVA ${ }^{1}$, Thaís Tibery ESPIR ${ }^{1,2}$, Maricleide de Farias NAIFF ${ }^{1}$, Luis Henrique \\ Monteiro GOMES ${ }^{1,2}$, Flávia Regina Almeida Campos Naief MOREIRA ${ }^{3}$, Antonia Maria Ramos FRANCO ${ }^{1^{*}}$ \\ 1 Instituto Nacional de Pesquisas da Amazônia (INPA), Leishmaniasis and Chagas Disease Laboratory, Coordination of Research in Society, Environment and Health, Av. André \\ Araújo, 2936, 69080-971, Manaus, Amazonas, Brazil. \\ 2 Universidade Federal do Amazonas, Multidiscilplinar Program of Post-graduation in Biotechnology (PPGBiotec), Av. General Rodrigo Otávio, 6200, 69080-900, Manaus, \\ Amazonas, Brazil. \\ ${ }^{3}$ Universidade Federal do Amazonas, Department of Physiological Sciences of the Institute of Biological Sciences (ICB), Av. General Rodrigo Otávio, 6200, 69080-900, Manaus, \\ Amazonas, Brazil \\ Corresponding Author: afranco@inpa.gov.br
}

\begin{abstract}
Few cases of human cutaneous leishmaniasis (CL) caused by Leishmania naiff were described in the medical literature. The aim of this study was to report and analyze new cases of $L$. naiff in the period between the years 1992 to 2011. The strains were characterized by isoenzyme analysis. All patients assisted had small lesions; ranging from $1.0 \times 1.0 \mathrm{~mm}$ and $13.5 \times 11.5$ $\mathrm{mm}$. The lesions observed were widely distributed: $55.5 \%$ on the lower limb, $5.5 \%$ in the abdominal area, $16.6 \%$ on upper limb and $22.2 \%$ in upper limb and back. Seventy-two percent of patients had ulcerated lesions. Clinical course of the disease varied from 1 to 10 months. According to gender, most infected individuals were men (83.3\%). The patients came from Amazonas (10), Pará (01) and Rondônia (01), north States of Brazil. Five patients were infected in experimental stations of the National Institute of Amazonian Research (INPA). Although the results of this study were similar to other reports in the literature, some of the patients had more of one skin lesion. It is also reported the first case of CL caused by L. naiffi in the State of Rondônia and identified an area of disease transmission in the experimental station of INPA.
\end{abstract}

KEYWORDS: American Tegumentary Leishmaniasis, Leishmania naiff, Characterization, experimental stations, Lutzomyia

\section{Novos relatos de casos de leishmaniose cutânea por Leishmania (Viannia) naiffi na região amazônica, Brasil}

\section{RESUMO}

Poucos casos de leishmaniose cutânea humana (LC) causada por Leishmania naiff foram descritos na literatura médica. Assim, o objetivo deste estudo foi relatar e analisar novos casos de infecçáo por $L$. naiffi no período compreendido entre os anos de 1992 a 2011. As cepas foram caracterizadas por análise de isoenzimas. Todos os pacientes atendidos apresentavam lesóes pequenas;

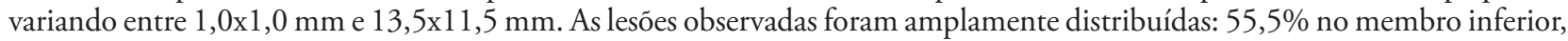
$5,5 \%$ na área abdominal, $16,6 \%$ no membro superior e $22,2 \%$ no membro superior e para trás. Setenta e dois por cento dos pacientes tiveram lesôes ulceradas. O curso clínico da doença variou de 1 a 10 meses. De acordo com o sexo, a maioria dos indivíduos infectados eram homens (83,3\%). Os pacientes vieram de Amazonas (10), Pará (01) e Rondônia (01), estados do norte do Brasil. Cinco pacientes foram infectados em estações experimentais do Instituto Nacional de Pesquisas da Amazônia (INPA). Embora os resultados encontrados neste estudo fossem semelhantes às outras descriçóes na literatura, alguns dos pacientes apresentavam mais de uma lesão cutânea. Também é relatado o primeiro caso de LC causada por L. naiffi no Estado de Rondônia e identificada uma área de transmissão da doença na estaçấo experimental do INPA.

PALAVRAS-CHAVE: Leishmaniose Tegumentar Americana, Leishmania naiffi, Caracterização, Estação experimental, Lutzomyia 


\section{INTRODUCTION}

American Cutaneous Leishmaniasis (ACL) is a zoonotic disease caused by protozoan parasites of the genus Leishmania. It is transmitted to humans by the bite of female sand flies from the genus Lutzomyia in the New World. The ACL in Brazil is common in many areas and has been reported in all states of Brazil. In the northern region of Brazil, there are seven species of Leishmania that are etiologic agents of the disease: Leishmania (Viannia) braziliensis, L. (V.) guyanensis, L. (V.) shawi, L. (V.) lainsoni, L. (V.) naiff, L. (V.) lindenbergi and L. (Leishmania) amazonensis (Silveira et al. 2002; Lainson and Shaw 2005). Disease severity ranges from a benign cutaneous form with spontaneous healing, to severe forms that are sometimes deforming, such as mucocutaneous leishmaniasis (Dorval et al. 2006).

There are only a few case reports of CL related to $L$. (V.) naiffi. It has a low degree of pathogenicity in humans, being associated only to the cutaneous form, which can have spontaneous cure in some cases (Naiff et al. 1991; Campos et al. 2008).

This species was described by Lainson and Shaw (1989). Its natural reservoir is the nine-banded armadillo, Dasypus novemcinctus. Five species of sand flies are involved in the transmission of the disease: Lutzomyia squamiventris (Naiff et al. 1991), Lu. paraensis, Lu. ayrozai, Lu. davisi (Grimaldi et al. 1991; Lainson et al. 1994) and Psychodopygus hirsutus (Gil et al. 2003). Very few cases of leishmaniasis caused by $L$. (V.) naiff have been reported in humans. There are case reports in Brazil, French Guiana, Ecuador, Suriname, the Caribbean island of Martinique and Peru (Pratlong et al. 2002; Fouque et al. 2007; Van Thiel et al. 2010). In Brazil, cases of human infection by $L$. (V.) naiffi were reported in the states of Amazonas, Acre, Pará and Mato Grosso (Tojal da Silva et al. 2006; Lainson 2010; Felinto de Brito et al. 2012). The main vector of infection in armadillos seems to be the sand fly $L u$. ayrozai. This species is not highly anthropophilic, and it is probably why there are reduced rates of infection with $L$. (V.) naiff in humans in Brazil (Lainson 2010).

In the present study, we describe and evaluate the clinical and epidemological aspects of new cases of cutaneous leishmaniasis caused by Leishmania (Viannia) naiffi, aquired from different locations in the Northern region of Brazil, that were diagnosed in the Laboratory of Leishmaniasis and Chagas Disease at INPA between the years of 1992 and 2011.

\section{MATERIALS AND METHODS}

\section{Clinical cases and Leishmania identification:}

All patients with CL characteristic lesions were examined. To confirm the diagnosis, parasites were isolated from samples obtained by scarifying the edge of skin lesions and inoculating the fragments in blood agar plates NNN (NovyMacNeal - Nicolle medium) with $3.0 \mathrm{~mL}$ Roswell Park
Memorial Institute medium 1640 (RPMI 1640; Invitrogen Corp., Carlsbad, CA) supplemented with L-glutamine, 10\% inactivated Fetal Bovine Serum (iFBS), 2 mM NaHCO3 and $\mathrm{pH}$ adjusted to 7.3 (10\% RPMI). The cultures were labeled with the patient's unique identifier and the date of collection, incubated vertically at 22 to $26^{\circ} \mathrm{C}$ under standard atmospheric conditions, and independently examined by two different investigators every 1 to 2 days under an inverted microscope at $400 \mathrm{X}$ magnification. The cultures were incubated and examined for 21 days before being considered negative. The imprinting of cutaneous lesions fragments were stained with panoptic and observed in order to identify amastigote forms in the lesion.

The cultures were expanded in complete Schneider medium ( $\mathrm{pH} 7,2$, with 10\% iFBS) to obtain the parasites that were used for experimental infection, biochemical characterization and cryopreservation. For experimental infection, hamsters were inoculated by intradermic injection on their snout region with $10^{6}$ stationary phase promastigotes $/ \mathrm{mL}$. The promastigotes were used in the stationary phase.

Parasite isolates were characterized by isoenzyme electrophoresis on agarose gel as previously described (Cupolillo et al. 1994). Eight enzyme systems were used: Malate Dehydrogenase (MDH, EC1.1.1.37), Isocitrate Dehydrogenase (IDH, EC1.1.1.42) with NAD or NADP, malic enzyme (ME, EC1.1.1.40), Glucose-6-phosphate dehydrogenase (G6PDH, EC1.1.1.49), 6-Phosphogluconate Dehydrogenase (6GPDH, EC1.1.1.44), Aconitate Hydratase (ACON, EC4.2.1.3) and hexokinase (HK, EC2.7.1.1). The samples were identified through enzymatic profile comparison with reference strains of L. (V.) braziliensis (MHOMBR/1975/M2903), L. (V.) guyanensis (MHOMBR1975M4147), L. (V.) naiffi (MDASBR/1979/M5533) e L. (L.) amazonensis (IFLA/ $\mathrm{BR} / 1967 / \mathrm{PH} 8)$.

Some patient's history parameters were also analyzed such as: elapsed time between appearance of lesions and diagnosis, age, origin, location and characteristics of lesions.

This study was conducted in accordance with the requirements of the National Health Council (resolution 196/96), and was approved by INPA's Ethics Committee on Research Involving Human Beings under protocol 193/2008. All study participants signed the informed consent form (ICF) agreeing to participate in the study.

\section{RESULTS}

In the present work, 12 strains identified by isoenzyme analysis as $L$. ( $V$. naiffi were isolated from patients with CL. These patients came from the states of Amazonas (10), Pará (01) and Rondônia (01) [Table 1]. One patient of Amazonas was infected 
Table 1. Clinical and epidemiological characteristics of patients infected with Leishmania (Viannia) naiffi.

\begin{tabular}{|c|c|c|c|c|c|c|c|c|}
\hline International code ${ }^{\mathrm{a}}$ & Geographical origin & Age (years) & Sex & $\begin{array}{c}\text { Number } \\
\text { of } \\
\text { lesions }\end{array}$ & $\begin{array}{l}\text { Disease } \\
\text { progression } \\
\text { (Months) }\end{array}$ & Lesion site & $\begin{array}{l}\text { Lesion } \\
\text { size }(\mathrm{mm})\end{array}$ & $\begin{array}{c}\text { Lesion } \\
\text { characteristics }\end{array}$ \\
\hline MHOM/BR/1992/IM3829 & RO & 35 & M & 01 & 10 & Leg & $10.0 \times 14.0$ & Ulcerated \\
\hline MHOM/BR/1993/IM3936 & AM & 40 & M & 02 & 09 & Leg & $\begin{array}{l}10.5 \times 10.5 \\
13.5 \times 11.5\end{array}$ & Ulcerated \\
\hline MHOM/BR/1993/IM4000 & AM / ZF2 & 30 & M & 01 & 06 & Abdomen & $7.3 \times 7.3$ & Nodular \\
\hline MHOM/BR/1996/IM4315 & AM & 40 & M & 01 & 02 & Leg & $12.5 \times 12.5$ & Ulcerated \\
\hline MHOM/BR/1997/IM4366 & AM & 59 & M & 01 & 03 & Arm & $10.0 \times 10.0$ & Ulcerated \\
\hline MHOM/BR/2006/IM5333 & AM & 21 & $\mathrm{~F}$ & 02 & 01 & Leg & $\begin{array}{l}3.1 \times 2.4 \\
2.6 \times 2.2\end{array}$ & Papular \\
\hline MHOM/BR/2009/IM5549 & AM /ZF3, km 41 & 31 & M & 01 & 04 & Arm & $3.0 \times 4.0$ & Ulcerated \\
\hline MHOM/BR/2009/IM5553 & ZF3 /Esteio & 34 & M & 01 & 04 & Arm & ND & Ulcerated \\
\hline MHOM/BR/2009/IM5557 & PA & 27 & $\mathrm{~F}$ & 02 & 09 & Arm and forearm & $3.0 \times 3.0$ & ND \\
\hline MHOM/BR/2009/IM5562 & AM/ZF2/ESTA & 26 & M & 02 & 04 & Arm and back & $\begin{array}{l}1.0 \times 1.0(\mathrm{arm}) \\
2.0 \times 2.0 \text { (back) }\end{array}$ & Ulcerated \\
\hline MHOM/BR/2010/IM5665 & AM & 23 & M & 03 & 01 & Leg & 8.0 x 6.0 (major) & Ulcerated \\
\hline MHOM/BR/2011/IM6032 & AM/ZF3, Km 37 & 32 & M & 01 & 01 & Leg & $8.0 \times 12.0$ & Ulcerated \\
\hline
\end{tabular}

a: designation: host [M = Mammalia: HOM: Homo sapiens/country of origin /lsolation year/ Source Code]. BR: Brazil; RO: Rondônia; AM: Amazonas; PA; Pará. ESTA: Experimental Station of Tropical Agroforestry; ND: not defined

twice, the second infection was one year after the first (MHOM/ BR/2009/IM5549 and MHOM/BR/2010/IM6032 strains).

Lesions in such patients were small, ranging from $1.0 \mathrm{x}$ $1.0 \mathrm{~mm}$ to $13.5 \times 11.5 \mathrm{~mm}$ (Figure 1 , Table). Among them, seven patients $(58.3 \%)$ had one lesion, four $(33.3 \%)$ had two lesions and one (8.3\%) had three lesions. In most cases (72\%), the lesions were ulcerated. Regarding the body location of the lesions, 55.5\% were in the lower limbs (10), 5.5\% in the abdominal region (01), 16.6\% in the upper limbs (03) and $22.2 \%$ in the upper limb and back (04). The development of the disease varied between one and ten months. Ten patients (83.3\%) were men and two were women (16.7\%) [Table].

A total of five (41.7\%) samples were isolated from patients who reported to have contracted the infection in INPA's Experimental Stations, ZF2 and ZF3 (three infections occurred in ZF3 and two in ZF2 (Figure 2, Table). These patients reported that they had visited this forest area in the last few months prior to the diagnosis of infection, and they thought that the transmission of disease was possibly a result of their visits to the field to carry out scientific research.

Laboratory animals were inoculated with the strains isolated from patients and did not show skin lesions after a period of observation of more than six months (INPA's Ethics Committee
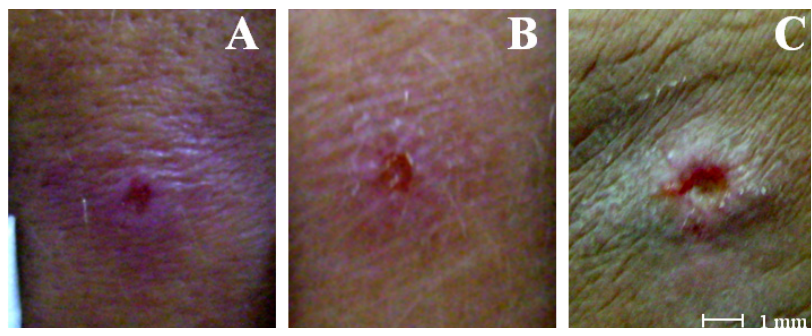

Figure 1. Ulcerated and papular lesions of patients with cutaneous leishmaniasis in Manaus, Amazonas, BR. Strains identified by enzyme electrophoresis as Leishmania (Viannia) naiffi: A-B: MHOM/BR/2009/IM5662, $\mathrm{C}: \mathrm{MHOM} / \mathrm{BR} / 2010 / \mathrm{IM} 5665$. The scale bars in panels $=1 \mathrm{~mm}$. This figure is in color in the electronic version. 


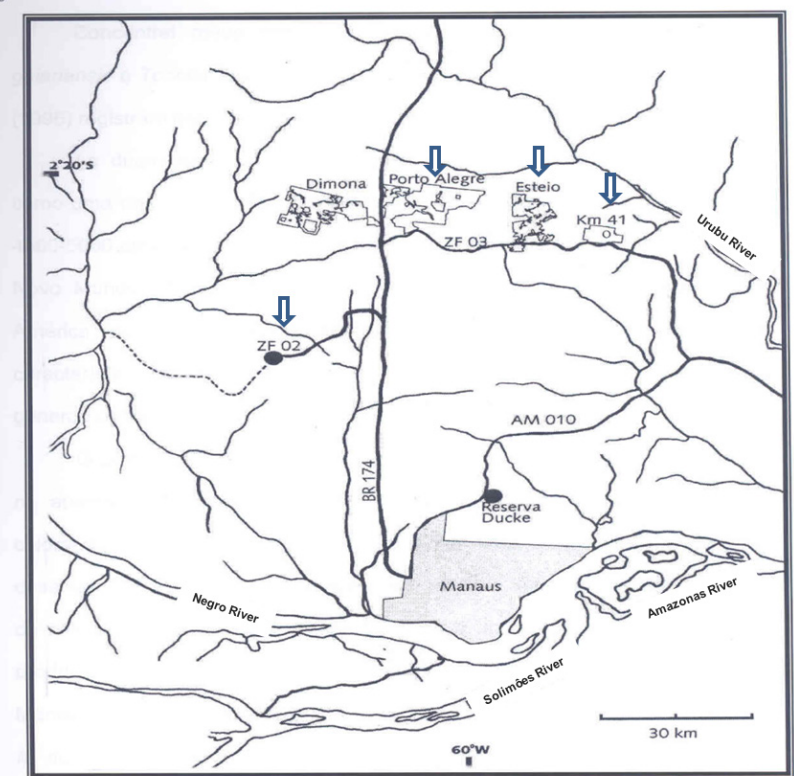

Figure 2. Map of the Central Amazon of Brazil, showing localization of experimental stations of the National Institute of Amazonian Research (INPA), Manaus, AM, Brazil. Arrows indicate the locality in which patients diagnosed with cutaneous leishmaniasis identified as Leishmania (Viannia) naiffi, reported that they had visited to carry out their scientific activities in the field. Source: http://pdbff.inpa.gov.br/download/mapimg/regmanauspdbff.jpg. This figure is in color in the electronic version.

on Animal Use $n^{\circ}$ 02/2014). However, the parasite could be isolated in culture from these animals one year after inoculation.

\section{DISCUSSION}

Until recently, just a few cases of CL caused by $L$. (V.) naiffi were described. Less than 15 cases of the disease were reported in Brazil before year 2010 (Naiff et al. 1991; Tojal et al. 2006; Figueira et al. 2008). In year 2011, nine isolates were identified from patients with CL caused by $L$. ( $V$. $)$ naiffi in Amazonas state, in an total of 209 strains. Also in this total, fifteen mixed infections, involving $L$. (V.) naiffi and $L$. (V.) guyanensis, $L$. (V.) braziliensis or $L$. (L.) amazonensis were also identified by the authors (Coelho et al., 2011). An occupational case of infection with $L$. (V.) naiffi that was acquired in Mato Grosso and diagnosed in Pernambuco was reported by Felinto de Brito et al. in 2012.

Patients with CL caused by $L$. (V.) naiffi usually presents a single lesion, small, ulcerated and mostly in the hands, arms and legs (Naiff et al. 1991; Silveira et al. 2008; Campos et al. 2008; Van Der Snoek et al. 2009). Similarly, the patients in this study had small lesions, most often ulcerated and localized on the arms and legs. Differing from other studies, five patients (41.6\%) presented more than one lesion. The proportion between infected men and women is similar to other literature information. Also similar was the average age of patients, most of them young adults (Chagas et al. 2006; Guerra et al. 2006, Coelho et al. 2011).

$L$. ( $V$.) naiffi parasites present low infectivity in experimentally infected $\mathrm{BALB} / \mathrm{c}$ mice macrophages; this is related to the low frequency of infection and low degree of pathogenicity in humans. These data suggest that this parasite can also yield a benign and hidden infection in humans, so the transmission is far more frequent than it is reported (Campos et al. 2008). Patients living in isolated areas of the Amazon region don't have easy access to health care. Since lesions caused by infection with $L$. (V.) naiff did not show an important progression in size, the diagnosis and treatment of disease are seriously delayed.

$L$. (V.) naiffi pathogen has been reported in other parts of Latin America, where mammal reservoirs and vectors coexist (Lainson 2010). In Panamá, the parasite was detected in Lu. trapidoi and Lu. gomezi (Azpurua et al. 2010). In the Amazonian region of Ecuador, natural infection of Lu. tortura with L.(V.) naiffi was detected by Kato et al. in 2008.

The absence of skin lesions in experimentally infected animals, made the CL diagnose difficult. The isolation of parasites was also difficult. This behavior was also observed by Lainson and Shaw (2005), in hamsters (Mesocricetus auratus) infected with this species.

In this study, 12 new CL cases caused by $L$. (V.) naiff were identified in northern Brazil. Five were derived from the Experimental Stations located in the INPA Forest Reservations, ZF2 and ZF3 (Figure 2). These areas are used in experimental research by researchers and graduate students and seems to play an important role in the transmission of CL in this region. In 2008, Figueira et al. isolated and identified five strains of $L$. (V.) naiffi. Among them, three strains were from patients who were infected in the area of Experimental Stations or in its vicinity. Two strains were isolated from INPA students who became infected in Esteio Reserve and the Porto Alegre Farm, both located in the ZF3 area; a third patient was infected in the vicinity of Km 21 of highway BR 174, Manaus, Amazonas, Brazil.

Researchers of the Chagas' Disease and Leishmaniasis Laboratory - INPA identified a total of 166 sand flies (ㅇ) distributed in 13 species, Lu. olmeca nociva with 48 (28.9\%) individuals captured, followed by Lu. flaviscutellata (25/15.1\%), Lu. rorotaensis (15/ 9\%), Lu. trichopyga (13/7.8\%), Lu. georgii (12/7.2\%), Lu. davisi (12/72\%), Lu. ruii $(9 / 5.4 \%)$, Lu. squamiventris squamiventris $(8 / 4.8 \%)$, Lu. ayrozai (8/4.8\%), Lu. umbratilis (7/4.2\%), Lu. anduzei (4/2.4\%), Lu. sordellii (3/1.8\%) and Lu. monstruosa (2/1.2\%), in the Experimental Stations Porto Alegre and Esteio, located in the area of Forest Fragments Biological Dynamics project - INPA (ZF3) [unpublished data]. 
Considering CL caused by $L$. (V.) naiffi case reports, as well as the identification of the species involved in the transmission of this pathogen at experimental stations ( $L u$. squamiventris, $L u$. davisi and $L u$. ayroza in ZF3 - Porto Alegre and Esteio areas and $L u$. squamiventris, $L u$. davisi, $L u$. ayrozai and $L u$. paraensis in ZF2 (Dias-Lima, Castellón, Sherlock 2003), we suggest that these places have potential as transmission areas of this parasite species.

Although Lu. ayrozai is not considered highly anthropophilic in the state of Pará (Lainson et al. 1994; Lainson and Shaw 1998), most infections by $L$. (V.) naiffi are transmitted by this vector. In the regions of the southeast of Brazil, this sand fly specie is considered highly anthropophilic (Aguiar and Soucasaux 1984), as in Serra dos Órgãos, Rio de Janeiro (Aguiar et al. 1985) and in Vale do Ribeira, São Paulo state (Gomes and Galati 1989).

Another highlight of this work is the report of the first isolation of $L$. (V.) naiff from a patient (MHOM/BR/1992/ IM3829) who contracted the infection in Rolim de Moura, Rondônia State (Table). This species had been isolated from the armadillo Dasypus novemcinctus (Naiff et al. 1991), Psychodopygus hirsutus and Lu. davisi in this same state (Gil et al. 2003).

\section{CONCLUSION}

Our results are in accordance with the literature, although some patients displayed more than one lesion (41.6\%). We identified and described the first case by $L$. (V.) naiffi in a patient from Rondônia, Brazil and also cases from INPA reserves. Excluding the planned and controlled impacts (selective logging and isolation of forest fragments), in the INPA Reserve, the only activity allowed is scientific research. The reserve is in excellent condition, despite the possible impact caused by hunters and extractivists. More studies are necessary INPA's reserves to identify the vectors and reservoirs related to the transmission of $L$. (V.) naiffi and other species of Leishmania. These areas are used in experimental research by researchers and graduate students from various courses. Therefore, the use of personal protective equipment is extremely important for field researchers to prevent infections in the future.

\section{ACKNOWLEDGEMENTS}

We wish to thanks Artemio Coelho da Silva, Francisco Lima Santos and Roberto Dantas de Farias for technical support in the field. This study was financially supported by INPA/MCTI and National Research Council (CNPq) and part of the Luanda de Paula Figueira Thesis.

\section{REFERENCES}

Aguiar, G.M.; Vilela, M.L.; Schuback, P.D.; Soucasaux, T.; Azevedo, A.C.R. 1985. Aspectos da ecologia dos flebótomos do Parque
Nacional da Serra dos Órgãos, Rio de Janeiro. IV — Freqüência mensal em armadilhas luminosas (Diptera, Psychodidae: Phlebotominae). Memórias do Instituto Oswaldo Cruz, 80: 465-482.

Aguiar, G.M.; Soucasaux, T. 1984. Aspectos da ecologia dos flebótomos do Parque Nacional da Serra dos Órgãos, Rio de Janeiro. I - Freqüência mensal em isca humana (Diptera, Psychodidae: Phlebotominae). Memórias do Instituto Oswaldo Cruz, 79: 197-209.

Azpurua, J.; De La Cruz, D.; Valderama, A.; Windsor, D. 2010. Lutzomyia sand fly diversity and rates of infection by Wolbachia and an exotic Leishmania species on Barro Colorado Island, Panama. PLoS Neglected Tropical Diseases, 4: 627.

Campos, M.B.; De Castro Gomes, C.M.; De Souza, A.A.; Lainson, R.; Corbett, C.E.; Silveira, F.T. 2008. In vitro infectivity of species of Leishmania (Viannia) responsible for American cutaneous leishmaniasis. Parasitology Research, 103:771-776.

Chagas, A.C; Pessoa, F.A.C.; Medeiros, J.F; Py-Daniel, V.; Mesquita, E.C.; Balestrassi, D.A. 2006. Leishmaniose tegumentar americana (LTA) em uma vila de exploração de minérios Pitinga, município de Presidente Figueiredo, Amazonas, Brasil. Revista Brasileira de Epidemiologia, 9: 186-192.

Coelho, L.I.C.; Paes, M.; Guerra, J.A.; Barbosa, M.G.; Coelho, C.; Lima, B.; Brito, M.E.; Brandão Filho, S.P. 2011. Characterization of Leishmania spp. causing cutaneous leishmaniasis in Manaus, Amazonas, Brazil. Parasitology Research, 108: 671-677.

Cupolillo, E.; Grimaldi, G. Jr.; Momen, H. 1994. A general classification of the New Word Leishmania using numerical zymotaxonomy. American Journal of the Tropical Medicine and Hygiene, 50:296-311.

Dias-Lima, A.G.; Castellón, E.; Sherlock, I. 2003. Flebotomíneos (Diptera: Psychodidae) de uma floresta primária de terra firme da Estação Experimental de Silvicultura Tropical, Estado do Amazonas, Brasil. Acta Amazonica, 33: 303-316.

Dorval, M.E.M.C.; Oshiro, E.T.; Cupollilo, E.; Castro, A.C.C.; Alves, T.P. 2006. Ocorrência de leishmaniose tegumentar americana no Estado do Mato Grosso do Sul associada à infecção por Leishmania (Leishmania) amazonensis. Revista da Sociedade Brasileira de Medicina Tropical, 39: 43-46.

Felinto de Brito, M.E.; Andrade, M.S.; De Almeida, É. L.; Medeiros, Â. C. Rapela; Werkhauser, R.P.; Araújo, A.I.F.; Brandão-Filho, S.P.; Paiva de Almeida, A.M.; Gomes Rodrigues, E.H. 2012. Occupationally Acquired Ameican Cutaneous leishmaniasis. Case reports. Dermatological Medicine, 2012: 1-4.

Figueira, L.P.; Zanotti, M.; Pinheiro, F.G.; Franco, A.M.R. 2008. Isoenzymatic characterization of human isolates of Leishmania sp (Kinetoplastida: Trypanosomatidae) from the municipalities of Rio Preto da Eva and Manaus, State of Amazonas. Revista da Sociedade Brasileira de Medicina Tropical, 41: 512-514.

Fouque, F.; Gaborit, P.; Issaly, J.; Carinci, R.; Gantier, J. C.; Ravel, C.; Dedet, J.P. 2007. Phlebotomine sand flies (Diptera: Psychodidae) associated with changing patterns in the transmission of the human cutaneous leishmaniasis in French Guiana. Memórias do Instituto Oswaldo Cruz, 102: 35-40. 
Guerra, J.A.O.; Ribeiro, J.A.S.; Coelho, L; Barbosa, M.G.V.; Paes, M.G. 2006. Epidemiologia da Leishmaniose Tegumentar na Comunidade São João, Manaus, Amazonas, Brasil. Caderno de Saúde Pública, 22: 2319-2327.

Gil, L.H.S.; Basano, S.A.; Souza, A.A.; Silva, M.G.S.; Barata, I.; Ishikawa, E.A.; Camargo, L.M.A.; Shaw, J.J. 2003. Recent observations on the sand fly (Diptera: Psychodidae) fauna of the state of Rondônia, western Amazônia, Brazil: the importance of Psychdopygus davisi as a vector of zoonotic Cutaneous Leishmaniasis. Memórias do Instituto Oswaldo Cruz, 98: 751-755.

Gomes, A.C.; Galati, E.A.C. 1989. Aspectos ecológicos da Leishmaniose Tegumentar Americana-Capacidade vetorial flebotomínea em ambiente florestal primário do sistema de Serra do Mar, região do Vale do Ribeira, Estado de São Paulo, Brasil. Revista Saúde Pública, 23: 136-42.

Grimaldi, G.Jr.; Momen, H.; Naiff, R.D.; Mcmahon-Pratt, D.; Barrett, T.V. 1991. Caracterization and classification of leishmanial parasites from humans, wild mammals, and sand flies in the Amazon Region of Brazil. Americam Journal of Tropical Medicine and Hygiene, 44: 645-661.

Kato, H.; Gomez, E.A.; Yamamoto, Y.; Calvopiña, M.; Guevara, A.G.; Marco, J.D. 2008. Natural Infection of Lutzomyia tortura with Leishmania (Viannia) naiffi in an Amazonian Area of Ecuador. American Journal of Tropical Medicine and Hygiene, 79: 438-440.

Lainson, R. 2010. Espécies neotropicais de Leishmania: uma breve revisão histórica sobre sua descoberta, ecologia e taxonomia. Revista Pan-Amazônica de Saude, 1: 13-32.

Lainson, R.; Shaw, J.J. 1989. Leishmania (Viannia) naiffi sp. n., a parasite of the armadillo, Dasypus novemcinctus ( $L$.) in Amazonian Brazil. Annals Parasitology Human Complement, 64:3-6.

Lainson, R.; Shaw, J.J. 2005. Leishmaniasis in the New World. In: Collier, L.; Balows, A.; Sussman, M. (Ed.). Topley \& Wilson's Microbiology and Microbial Infections. Parasitology, 5: 313-349.

Lainson, R.; Shaw, J.J.; Silveira, F.T.; Souza, A.A.A.; Braga, R.R.; Ishikawa, E.A.Y. 1994. The dermal leishmaniases of Brazil, with special reference to the eco-epidemiology of the disease in Amazonia. Memórias do Instituto Oswaldo Cruz, 89: 435-443.
Lainson, R.; Shaw, J.J. 1998. New World Leishmaniasis - The Neotropical Leishmania Species. In: Cox, F.E.G.; Kreier, J.P.; Wakelin, D. (Ed.). Topley \& Wilson's Microbiology and Microbial Infections. Parasitology, 9: 242-266.

Naiff, R.D.; Freitas, R.A.; Naiff, M.F.; Arias, J.R.; Barrett, T.V.; Momen, H.; Grimaldi Júnior, G. 1991. Epidemiological and nosological aspects of Leishmania naiffi Lainson \& Shaw, 1989. Memórias do Instituto Oswaldo Cruz, 86: 317-21.

Pratlong, F.; Deniau, M.; Darie, H.; Eichenlaub, S.; Proll, S.; Garrabe, E.; Le Guyadec, T.; Dedet, J.P. 2002. Human cutaneous leishmaniasis caused by Leishmania naiff is widespread in South America. Annals Tropical Medicine Parasitology, 96:781-785.

Silveira, F.T.; Ishikawa, E.A.; De Souza, A.A.; Lainson, R. 2002. An outbreak of cutaneous leishmaniasis among soldiers in Belém, Pará State, Brazil, caused by Leishmania (Viannia) lindenbergi n.sp. A new leishmanial parasite of man in the Amazon region. Parasite, 9: 43-50.

Silveira, F.T; Muller, S.R; Souza, A.A; Lainson, R; Gomes, C.M.C; Laurenti, M.D; Corbett, C.E.P. 2008. Revisão sobre a patogenia da Leishmaniose Tegumentar Americana na Amazônia, com ênfase à doença causada por Leishmania (V.) braziliensis e Leishmania (L.) amazonensis. Revista Paraense de Medicina, 22: 9-20.

Tojal Da Silva, A.C.; Cupolillo, E.; Volpini, A.C.; Almeida, R.; Romero, G.A. 2006. Species diversity causing human cutaneous leishmaniasis in Rio Branco, state of Acre, Brazil. Tropical Medicine International Health, 11:1388 - 1398.

Van der Snoek, E.M; Lammers, A.M; Kortbeek, L.M; Roelfsema, J.H; Bart, A; Jaspers, C.A. 2009. Spontaneous cure of American cutaneous leishmaniasis due to Leishmania naiffi in two Dutch infantry soldiers. Clinical and Experimental Dermatology, 34: 889-891.

Van Thiel, P.P.A.M.; Van Gool, T.; Kager, P.A.; Bart, A. 2010. First Cases of Cutaneous Leishmaniasis Caused by Leishmania (Viannia) naiff Infection in Surinam. American Journal of Tropical Medicine and Hygiene, 82: 588-590.

Received: 24/05/2016

Accepted: 12/09/2016 